\title{
Spontaneous coronary artery dissection: a complete resolution with medical treatment
}

\author{
Abdullah Sayied Abdullah, Hisham Ibrahim, Thomas J Kiernan
}

Department of Cardiology, University Hospital Limerick, Limerick, Ireland

\section{Correspondence to} Dr Abdullah Sayied Abdullah, abdalasayid@gmail.com

Accepted 25 September 2014

\section{DESCRIPTION}

A 28-year-old man, with no risk factors for coronary artery disease (CAD) and with a history of recent anabolic steroid use and intense anaerobic exercise, presented with chest pain, inferior $\mathrm{T}$ Wave changes and elevated troponin. A non-ST segment elevation myocardial infarction (NSTEMI) was diagnosed. Coronary angiography revealed spontaneous right coronary artery (RCA) dissection extending from proximal to distal (video 1 and figure 1).

The patient was managed medically with aspirin, clopidogrel and low molecular weight heparin. Repeat angiography after 1 week revealed almost complete resolution of the spontaneous RCA dissection (video 2 and figure 2).



Video 1 RCA coronary angiography: RCA dissection with poor distal flow.

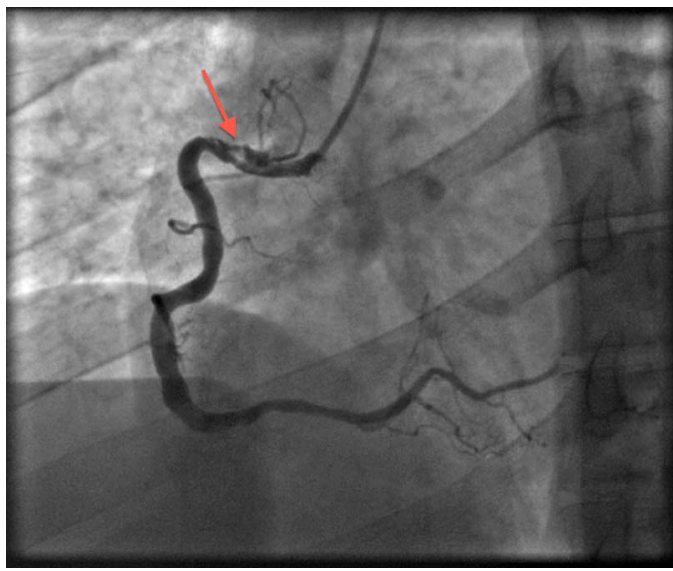

Figure 1 Right coronary artery dissection with double lumen appearance (arrow).

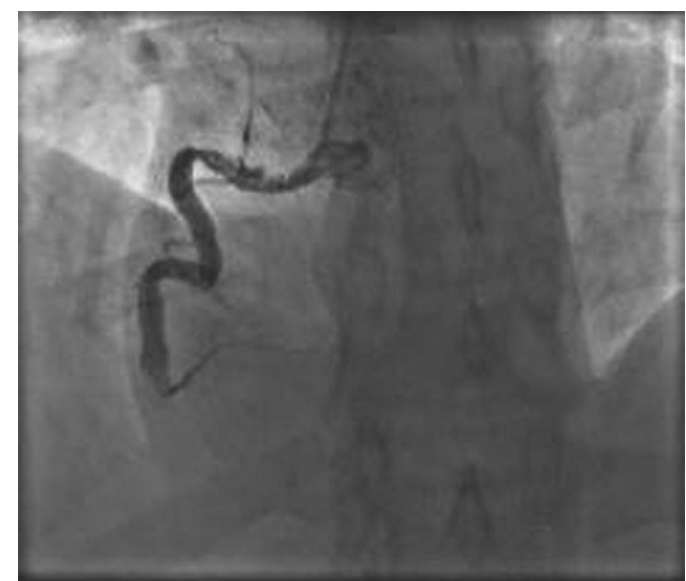

Video 2 RCA coronary angiography after 1 week of medical therapy.

Spontaneous coronary artery dissection is an unusual cause of myocardial infarction in young patients with low risk of atherosclerotic CAD. Causes are unknown, but it has been associated with the postpartum period, renal fibromuscular dysplasia and connective tissue diseases. ${ }^{1}{ }^{2}$ Management is difficult, however, medical treatment is reported to be effective but percutaneous coronary intervention is associated with poorer outcome. ${ }^{1}{ }^{2}$ The potential problem during coronary bypass graft surgery is identifying and grafting the true lumen rather than the false lumen.

This case illustrates the success of conservative treatment in cases of spontaneous coronary artery dissection. It also draws attention to the use of

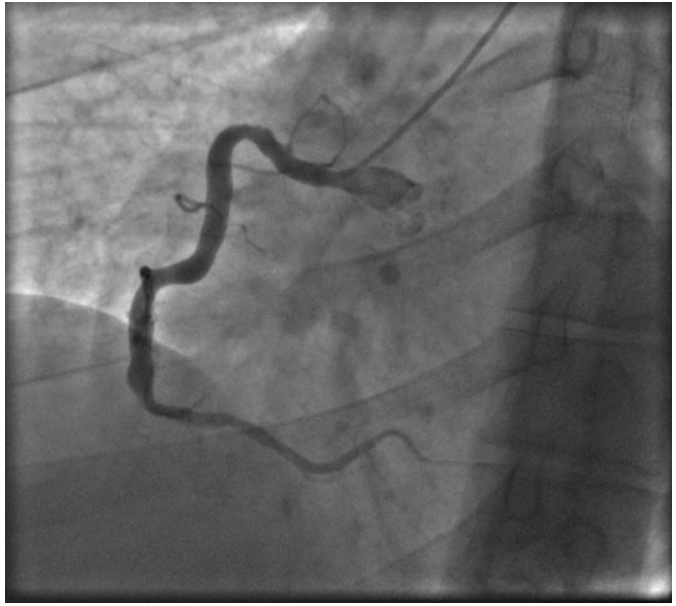

Figure 2 Image of right coronary artery after resolution. 
anabolic steroids and intense anabolic exercise as possible associations with spontaneous coronary artery dissection.

\section{Learning points}

- Consider coronary artery dissection in young patients with acute coronary syndrome.

- Medical management of coronary artery dissection is effective.

- Detailed history is important to elucidate risk factors for coronary artery disease.
Contributors ASA wrote the original manuscript and edited the final one, and treated the patient. $\mathrm{HI}$ edited the manuscript and participated in the management of the patient. TK is the principal physician in this patient treatment, and edited the manuscript.

Competing interests None.

Patient consent Obtained.

Provenance and peer review Not commissioned; externally peer reviewed.

\section{REFERENCES}

1 Tweet MS, Hayes SN, Pitta SR, et al. Clinical features, management, and prognosis of spontaneous coronary artery dissection. Circulation 2012;126:579-88.

2 Hayes SN. Spontaneous coronary artery dissection (SCAD): new insights into this not-so-rare condition. Tex Heart Inst J 2014:41:295-8.

Copyright 2014 BMJ Publishing Group. All rights reserved. For permission to reuse any of this content visit http://group.bmj.com/group/rights-licensing/permissions.

BMJ Case Report Fellows may re-use this article for personal use and teaching without any further permission.

Become a Fellow of BMJ Case Reports today and you can:

- Submit as many cases as you like

- Enjoy fast sympathetic peer review and rapid publication of accepted articles

- Access all the published articles

- Re-use any of the published material for personal use and teaching without further permission

For information on Institutional Fellowships contact consortiasales@bmjgroup.com

Visit casereports.bmj.com for more articles like this and to become a Fellow 